\title{
THE PRESENCE OF AIKINITE IN THE ABERDEEN AREA OF THE KIRKI MINE, WESTERN THRACE, GREECE
}

\author{
Michael Nicolaou \\ The Hellenic Chemical Products \& Fertilizers Co. Ltd. Amalias 20, Athens 118, Greece \\ T. A. HäKLI \\ Research Laboratory of Exploration, The Outokumpu Co., Outokumpu, Finland
}

\section{ABSTRACT}

The presence of intermediate aikinites in the Aberdeen area of the Kirki mine, western Thrace, Greece, is reported. The composition of the aikinites varies between $2.6 \%-8.3 \% \mathrm{Cu}, 6.1 \%-19.5 \% \mathrm{~Pb}$ and $73.3 \%-54.8 \% \mathrm{Bi}$. In addition, a copper-bearing galenobismuthite was also identified. It is concluded that, rather than having quantized compositions, the intermediate aikinites more probably form a solid solution series between bismuthite and aikinite.

The region of Kirki in western Thrace, 20$25 \mathrm{~km} \mathrm{NW}$ of Alexandroupolis, has been known for its sulphide mineralisation since 1880. The Aberdeen area of the Kirki mine, which is situated on the NW slopes of the Kelebek mountain by the Kara-Dere creek at an altitude of $650 \mathrm{~m}$, was first explored 35 years ago (Maratos and Andronopoulos, 1965). Exploratory drifts were opened at that time to confirm the extent of a copper mineralisation which follows a pegmatitic vein within the metamorphic rocks, mainly amphibolites of the Rhodope crystalline massif.

The mineralogical composition of the ore obtained from the old excavations has been described by Maratos (1961). In addition to chalcopyrite, he identified pyrite, sphalerite, galena, enargite, bornite and rammelsbergite.
Exploration work has lately been resumed by restoring the old drifts. We have established the presence of minerals of the aikinite group in samples collected from these drifts. This is the first time that these fairly rare minerals have been identified in Greece. It should also be noted that the presence of a bismuth mineral has never been reported from the Kirki mines.

Aikinite occurs generally as more or less rounded or columnar inclusions in chalcopyrite or as granular aggregates among crystals of chalcopyrite or gangue. The polishing hardness observed is lower than that of chalcopyrite and the Vickers microhardness varies mainly between 150 and 182 (load 25 g). In grains with a low copper content, values as low as 96 were found.

In polished section the minerals under consideration are white in colour resembling galena. 
TABLE 1.

Electron microprobe analyses of aikinites and galenobismuthites $25 \mathrm{kV}, 0.2 \mu \mathrm{A}, \mathrm{LiF}$ and mica crystals.

\begin{tabular}{|c|c|c|c|c|c|c|c|c|c|c|c|c|}
\hline & \multicolumn{9}{|c|}{ Aikinites } & \multicolumn{3}{|c|}{ Galenobismuthites } \\
\hline & 1. & 2. & 3. & 4. & 5. & 6. & 7. & 8. & 9. & 10. & 11. & 12. \\
\hline $\mathrm{Cu} \ldots$ & 2.6 & 4.6 & 7.2 & 7.3 & 7.8 & 8.2 & 8.3 & 4.8 & 5.0 & 4.4 & 4.7 & 5.1 \\
\hline $\mathrm{Pb} \ldots$ & 6.1 & 12.4 & 15.5 & 17.3 & 16.9 & 19.5 & 17.4 & 18.2 & 18.4 & 27.4 & 27.3 & 27.1 \\
\hline $\mathrm{Bi} \ldots \ldots$ & 73.3 & 64.5 & 58.7 & 57.3 & 57.2 & 54.8 & 56.2 & 58.7 & 59.2 & 50.3 & 51.5 & 51.0 \\
\hline $\mathrm{s} \ldots \ldots$ & 18.6 & 19.4 & 18.4 & 18.8 & 18.9 & 17.7 & 17.4 & 18.0 & 18.3 & 17.5 & 17.6 & 17.5 \\
\hline Total & 100.6 & 100.9 & 99.8 & 100.7 & 100.8 & 100.2 & 99.3 & 99.7 & 100.9 & 99.6 & 101.1 & 100.7 \\
\hline
\end{tabular}

Inaccuracy: $\mathrm{Cu} \pm 0.1 \%$

$\mathrm{Pb} \pm 0.3 \%$

$\mathrm{Bi} \pm 0.3 \%$

$\mathrm{S} \pm 0.3 \%$

The reflectivity, measured photoelectrically in air for white light, ranges between 43 and $45.5 \%$ on randomly orientated sections. The reflection pleochroism varies from distinct to weak and the anisotropism from strong to moderate.

The electron microprobe analyses carried out by a Geoscan microanalyser revealed a considerable variation in the composition of the aikinite grains. The analyses listed in Table 1 show that no grains were encountered with a composition of aikinite proper but that all the crystals analysed represent intermediate members of the series bismuthite-aikinite. The copper content varies from $2.6 \%$ to $8.3 \%$ and the lead content from $6.1 \%$ to $19.5 \%$. At the same time, the bismuth content fluctuates between $73.3 \%$ and $54.8 \%$. It is characteristic of these minerals that the atomic copper to lead ratio, which according to the literature (e.g. Welin, 1967; Moore, 1967) generally approaches 1.0 , shows a significant variation and in such a way that the grains embedded in chalcopyrite invariably have a higher ratio than the crystals occurring in the quartz matrix. This is illustrated in Fig. 1, in which the analyses of aikinites were recalculated to $\mathrm{Cu}+$ $\mathrm{Pn}+\mathrm{Bi}=100$ and plotted into a triangle diagram. The line joining the $\mathrm{Bi}$ corner with the stoichiometric composition of aikinite shows that analyses $1-2$ and $3-7$ have a slight and moderate excess of copper respectively, whereas analyses 8 and 9 which represent aikinites in the quartz matrix, have an atomic copper to lead ratio of slightly less than 1.0 .

The unit cell dimensions of the aikinites, determined with a $114.6 \mathrm{~mm}$ powder camera using Ni-filtered Cu-radition, agree excellently with those reported e.g. by Welin (1967). The cell edges for the aikinite of analysis No 1 are $\mathrm{a}=$ $11.19 \pm 0.02 \AA, \mathrm{b}=11.32 \pm 0.02 \AA$ and $\mathrm{c}=3.98$ $\pm 0.02 \AA$ and those for the aikinite of analysis No $5 \mathrm{a}=11.26 \pm 0.04 \AA, \mathrm{b}=11.40 \pm 0.02 \AA$ and $\mathrm{c}=3.98 \pm 0.01 \AA$, respectively.

A few grains of copper-bearing galenobismuthite (analyses Nos 10 to 12) were also encountered in the samples studied. The cell edges of this mineral, i.e. $\mathrm{a}=11.93 \pm 0.03 \AA, \mathrm{b}=$

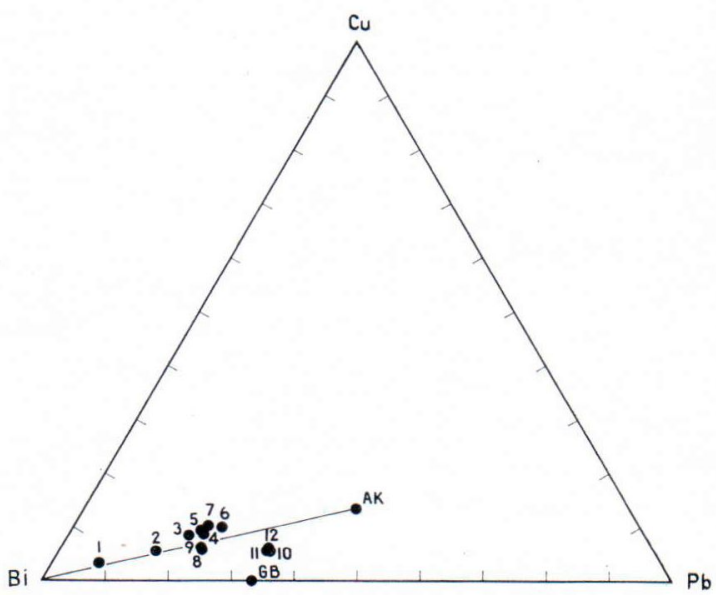

Fig. 1. Electron microprobe analyses of intermediate aikinites and copper-bearing galenobismuthites recalculated to $\mathrm{Cu}+\mathrm{Pb}+\mathrm{Bi}=100$ and plotted into a triangle diagram. $A K$ and $G B$ stand for aikinite and galenobismuthite, respectively. 
$14.78 \pm 0.07 \AA$ and $c=4.12 \pm 0.03 \AA$, are distinctly longer than those of a pure galenobismuthite (ASTM 11-138: $\mathrm{a}=11.74 \AA, \mathrm{b}=$ 14.55 and $\mathrm{c}=4.08 \AA)$.

Moore (1967) has suggested that only quantized compositions could exist within the series bismuthite-aikinite. According to this concept, aikinite is generated by substituting lead for part of the bismuth atoms in bismuthite and balancing the charge by the addition of copper mole-equivalent to the lead. Based on the general structure cell formula for the aikinite derivatives, i.e.

$$
\mathrm{Cu}_{\mathrm{x}} \mathrm{Pb}_{\mathrm{x}} \mathrm{Bi}_{8 \mathrm{z}-\mathrm{x}} \mathrm{S}_{12 \mathrm{z}}
$$

where $z$ is the integral multiple of the a-translation in aikinite for the superstructure, Moore (1967) calculated the weight percentages for the intermediate aikinites. The comparison of these percentages with those reported in the present study, making due allowance for analytical inaccuracy, indicates, however, that rather than being quantized, the composition of the aikinites seems to vary ramdomly, thus suggesting a solid solution series between bismuthite and aikinite.

Acknowledgements - The authors are indebted to the Outokumpu Company and the Hellenic Chemical Products and Fertilizers Company Ltd. for permission to publish the present paper.

\section{REFERENCES}

Maratos, G. (1961) Etude mineralogique du minerai de Kirki, Aberdin, King-Arthur etc. (Thrace). Metallogenie. Bull. Geol. Soc. Greece, 4.

Maratos, G. and Andronopoulos, B. (1965) The Kirka mines, Report No 35. Institute for Geology and Subsurface Research. Athens.
Moore, Paul B. (1967) A classification of sulfosalt structures derived from the structure of aikinite. Amer. Mineral. Vol. 52, pp. 1874-1876.

Welin, Eric (1967) Notes on the mineralogy of Sweden. 5. Bismuth-bearing sulphosalts from Gladhammar, a revision. Ark. Min. Geol. Band 4 nr 13, pp. 377386.

Manuscript received, July 2, 1969 